\title{
Limitation of spatial distribution of ammonia-oxidizing microorganisms in the Haihe River, China, by heavy metals
}

\author{
Chao Wang ${ }^{1,2}$, Baoqing Shan ${ }^{1, *}$, Hong Zhang $^{1}$, Yu Zhao ${ }^{1}$ \\ 1. State Key Laboratory on Environmental Aquatic Chemistry, Research Center for Eco-Environmental Sciences, Chinese Academy of Sciences, Beijing \\ 100085, China.E-mail: cwwhu@163.com \\ 2. University of Chinese Academy of Sciences, Beijing 100049, China
}

\section{A R T I C L E I N F O}

\section{Article history:}

Received 22 April 2013

revised 04 June 2013

accepted 08 June 2013

\section{Keywords:}

heavy metals

AOA

AOB

Haihe River

DOI: $10.1016 / \mathrm{S} 1001-0742(13) 60443-\mathrm{X}$

\begin{abstract}
A B S T R A C T
The Haihe River is characterized by high ammonia pollution. Therefore, it is necessary to determine how environmental factors, such as heavy metals in the river limit the spatial distribution of ammonia-oxidizing microorganisms. In this study, the relationships between five heavy metals and ammonia-oxidizing microorganisms were studied. The results showed that under high ammonia, low oxygen and high concentrations of suspended particles, ammonia-oxidizing bacteria (AOB) ranged from $10^{1.3}$ to $10^{4.8}$ gene copies/mL and ammonia-oxidizing archaea (AOA) ranged from $10^{2.7}$ to $10^{4.9}$ gene copies $/ \mathrm{mL}$. The average metal concentrations in water were $23.57(\mathrm{Cr}), 21.58(\mathrm{Ni}), 65.09(\mathrm{Cu})$, $622.03(\mathrm{Zn})$ and 10.16 (As) $\mu \mathrm{g} / \mathrm{L}$, with those of $\mathrm{Zn}, \mathrm{Cu}$ and $\mathrm{Cr}$ being higher than the US EPA criteria. Scatter plots of microbial abundance and metals indicated that both AOA and AOB were limited by heavy metals, but in different ways. As had an inhibitory effect on AOB, while Ni and $\mathrm{Zn}$ promoted AOA, and the other metals investigated showed no significant correlation with microbial abundance. Overall, our results indicated that the effects of heavy metals on ammonia-oxidizing microorganisms in water are complex, and that the final effect is determined by the physiological role of each element in the microorganisms, as well as environmental conditions such as complexation of organic matter, not simply the total metal concentration.
\end{abstract}

\section{Introduction}

Ammonia-oxidizing microorganisms are key drivers of ammonia oxidation, which is an important process in the nitrogen cycle. Ammonia-oxidizing bacteria (AOB) have been studied for many years and are known to be widespread in soil, freshwater and marine systems. Until recently, it was assumed that autotrophic ammonia oxidation was restricted to ammonia-oxidizing bacteria. However, this changed with the detection of a unique ammonia monooxygenase gene on an archaeal-associated scaffold (Venter et al., 2004) and on genomic fragments of archaea (Treusch et al., 2005), and the discovery of

\footnotetext{
${ }^{*}$ Corresponding author. E-mail: bqshan@ $@$ rcees.ac.cn
}

ammonia-oxidizing archaea (AOA) greatly expanded our understanding of ammonia oxidation (Francis et al., 2007).

The distribution of $\mathrm{AOA}$ and $\mathrm{AOB}$ is related to environmental conditions such as ammonia level, dissolved oxygen, acidity, temperature and salinity. The AOB population has been found to be larger in fertilized $\left(\left(\mathrm{NH}_{4}\right)_{2} \mathrm{SO}_{4}\right)$ than unfertilized soil (Okano et al., 2004); however, AOA have been shown to be more tolerant to low ammonium concentrations owing to their ammonia oxidation kinetics (Martens-Habbena et al., 2009). It is likely that AOA tolerate a wide range of oxygen levels and that some ecotypes are more suited to low-oxygen environments (Erguder et al., 2009). However, the abundance and community composition of AOB can change dramatically with the gradient of oxygen (Schramm et al., 2000). The role of $\mathrm{pH}$ in determining the distribution of $\mathrm{AOA}$ and $\mathrm{AOB}$ has been 
shown in many studies. Allison and Prosser (1993) found that Nitrosospira cluster 2 was more abundant in lower $\mathrm{pH}$ soil, while He et al. (2007) stated that archaeal amoA gene abundance decreased with increasing soil $\mathrm{pH}$. Moreover, many studies have shown that salinity and temperature influence the abundance or community structure of AOA and $\mathrm{AOB}$ to a great extent (Erguder et al., 2009; Koops and Pommerening-Röser, 2006).

Heavy metals comprise a common environmental factor that plays a role in shaping the ecological niches of ammonia-oxidizing microorganisms; therefore, they have received increasing attention. The effects of $\mathrm{Cu}$ (Mertens et al., 2010; Li et al., 2009), Zn (Mertens et al., 2009; Ruyters et al., 2010), and $\mathrm{Hg}$ (Liu et al., 2010) on the ammoniaoxidizing community have been well documented. AOA and $\mathrm{AOB}$ have been found to possess different adaptabilities to environmental stress. It was reported that the recovery of nitrification after 3-year $\mathrm{Zn}$ contamination was meditated by $\mathrm{AOB}$ rather than AOA, which meant AOB can adapt to $\mathrm{Zn}$ contamination better than AOA (Mertens et al., 2009). Mertens et al. (2010) found the increased $\mathrm{Cu}$ tolerance of the nitrifying community in long-term $\mathrm{Cu}$-exposed field sites was associated with changes in community structure. However, in a $\mathrm{Cu}$ inhibitory experiment, the abundance decrease of AOA was much less than that of $\mathrm{AOB}$, indicating that $\mathrm{AOA}$ was more tolerant than AOB (Li et al., 2009). $\mathrm{Hg}$ pollution also changed the composition of soil AOB to some extent and inhibited the soil potential nitrification rate (Liu et al., 2010). It seems that the response of the nitrifying community to heavy metals relates to the metal content and metal type as well as the exposure time.

In fact, the mechanisms through which heavy metals impact microorganisms are complex. In addition to being toxic at high levels, low levels of heavy metals can inhibit the growth of microbes because some elements are necessary in certain physiological processes (Stumm et al., 1996). The ecological effects of heavy metals are also closely related to the speciation of the elements, which determines their bioavailability and mobility in the environment (Brümmer et al., 2007). Most studies that have been conducted to date have involved soil; therefore, the behavior of heavy metals in the liquid phase needs more attention. Metals in soil can be strongly bound by organic materials such as humic and fulvic acids, and their mobility is poor (Giller et al., 1998). In contrast, metals in aquatic habitats have weaker binding effects and stronger mobility, and interact more easily with microbes. Accordingly, it is necessary to increase our knowledge of the effects of heavy metals on ammonia-oxidizing microorganisms in aquatic environments.

The Haihe River is one of the most important systems in China. Beijing and Tianjin are located within its basin, which is characterized by high population density, rapid socioeconomic development and serious water pollution caused by the discharge of industrial and domestic wastewater. Water quality monitoring of the Haihe River has revealed high ammonia levels and indicated that this has become one of the most prominent water quality problems in the river in recent years. Because ammonia-oxidizing microorganisms play a significant role in the reduction of ammonia, it is essential to understand their distribution and how they respond to environmental factors such as heavy metals. In this study, the Fuyang River, a typical river in the Haihe River Basin, was selected as the study area. Heavy metal concentrations in the water and the abundance of AOA and AOB in the suspended solids were measured.

Our overall objective was to investigate the relationship between ammonia-oxidizing microorganisms and heavy metals through field survey data by statistical methods.

\section{Materials and methods}

\subsection{Study area and sampling site}

The Haihe River Basin is located in the north of China and has an area of about $300,000 \mathrm{~km}^{2}$ and a population of 145 million. Beijing, Tianjin and many other cities are in this river basin and its urbanization level is over $45 \%$. In 2007, the amount of ammonia discharged into the river by domestic sewage and industrial wastewater was as high as 61,700 tons, and ammonia is always the main factor found to be degrading the water quality. The Fuyang River $\left(36^{\circ} 23^{\prime}-38^{\circ} 14^{\prime} \mathrm{N}, 114^{\circ} 19^{\prime}-116^{\circ} 7^{\prime} \mathrm{E}\right)$ is a well-known tributary of the Haihe River (Fig. 1) that receives the largest amount of ammonia. In addition, great differences in heavy metal concentrations may exist in the complex river system and large watershed of the Fuyang River. Therefore, the Fuyang River was selected as the sampling area.

The Fuyang River originates from mountains in Handan and ends at its confluence with the Hutuo River. The length of the main channel is $402 \mathrm{~km}$. The New Fuyang River, which was constructed for the purpose of flood diversion, runs parallel to the downstream portion of the Fuyang River. Additionally, the Xiao River, Wangyang Ditch and Shaocun Ditch are tributaries of the Fuyang River that receive domestic wastewater, pharmaceutical wastewater and tannery wastewater, respectively, from Shijiazhuang. The Li River is another tributary of the Fuyang River system that receives a large amount of domestic and industrial wastewater from Xingtai. In addition, the mainstream of the Fuyang River primarily receives wastewater from Handan and Hengshui. In 2007, a total of 0.52 billion tons of wastewater were discharged into the river system, among which domestic sewage and industrial wastewater accounted for $50 \%$ each. This high pollution discharge results in deterioration of water quality, and ammonia is the primary pollutant in most rivers. 


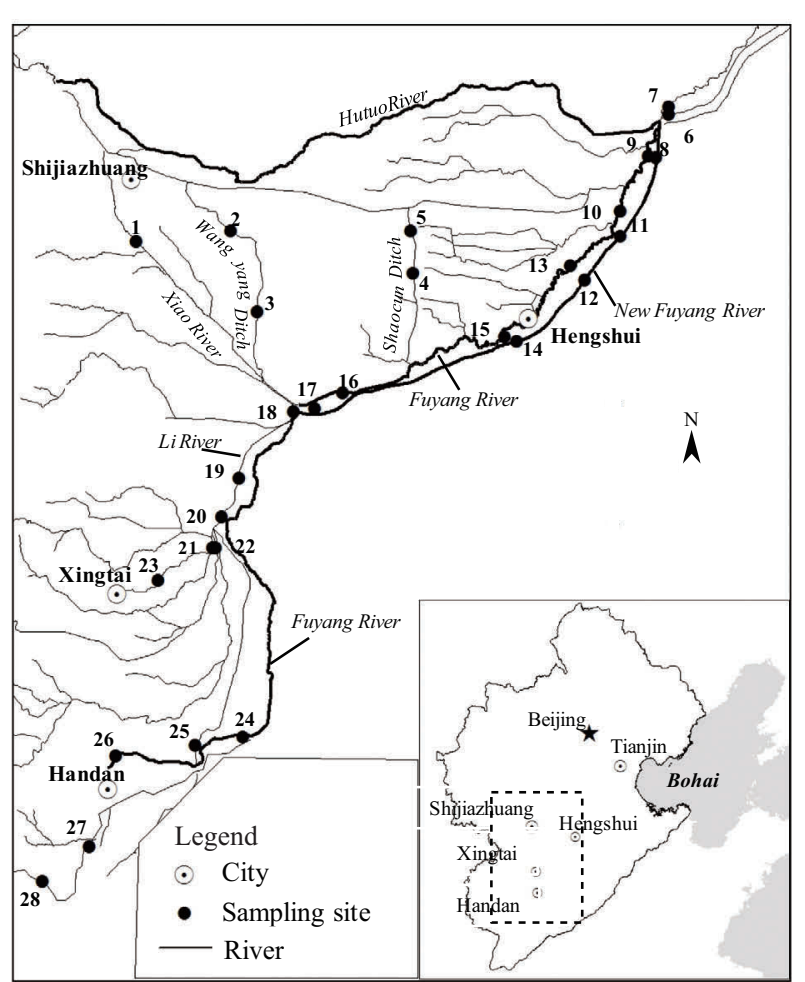

Fig. 1 Study area and sampling sites (1-28). The solid line in the inset is the boundary of the Haihe River Basin and the dashed frame represents the spatial extent.

We divided the Fuyang River system into four parts based on the four cities involved. A total of 28 sampling sites were set over the entire river system, with 5 to 10 sample sites in each part. All the sites were numbered from 1 to 28 , with sites 1 to 5 being located in Shijiazhuang, sites 6 to 15 in Hengshui, sites 16 to 23 in Xingtai and sites 24 to 28 in Handan (Fig. 1).

\subsection{Sample collection and analysis}

Sample collection was carried out in July 2011. Physicochemical parameters including temperature, $\mathrm{pH}$ and dissolved oxygen were measured using a handheld multiparameter instrument (YSI 556, Yellow Springs, USA). Water samples were collected at the surface. All samples were divided into two parts, one that was filtered using a Millipore filter $(\Phi 0.45 \mu \mathrm{m})$ and stored for chemical analysis in $50 \mathrm{~mL}$ acid-washed polyethylene sample bottles after acidification with $1 \mathrm{~mL} 1: 1(V / V)$ deionized water diluted $\mathrm{H}_{2} \mathrm{SO}_{4}$, and another that was stored in $500 \mathrm{~mL}$ presterilized polyethylene sample bottles for DNA extraction. All samples were frozen and stored at $-18^{\circ} \mathrm{C}$ immediately upon returning from the field.

Samples were analyzed for $\mathrm{Cr}, \mathrm{Ni}, \mathrm{Cu}, \mathrm{As}$ and $\mathrm{Zn}$ using an Inductively Coupled Plasma Mass Spectrometer (ICP-MS) according to standard methods (Clesceri et al., 1998). Selection of these five metals was made based on the industrial structure in the Fuyang River Basin, where tannery, machine manufacturing, pharmacy and livestock operations are intensive. $\mathrm{Cr}$ content is high in the tannery wastewater, Ni mainly comes from machine manufacturing wastewater, $\mathrm{Cu}$ and $\mathrm{Zn}$ are abundant in pharmaceutical wastewater, and As discharge is high in livestock wastewater. Total organic carbon (TOC) was measured with a TOC analyzer (Shimadzu TOC-VCPH, Kyoto, Japan) and was calculated by subtracting the inorganic carbon from the total carbon. Ammonia was measured using a SmartChem ${ }^{\circledR} 200$ discrete chemistry analyzer (Westco Scientific Instruments, USA) following US EPA method 350.1, in which the ammonia nitrogen content is determined by semi-automated colorimetry.

We used real-time quantitative PCR, which measures microbial abundance through DNA copy numbers (Ginzinger, 2002), to measure the abundance of ammoniaoxidizing microorganisms. To accomplish this, DNA was extracted from particles suspended in the water. Briefly, particles in the water samples were collected by vacuum filtration using a Millipore filter ( $\Phi \quad 0.45 \mu \mathrm{m}$ ). When the solute no longer dripped down, filtering was stopped and the volume of filtered water was recorded. The filter membrane was weighed before and after filtering, and the difference was divided by the volume of filtered water, which gave the concentration of suspended particles. The particles were then transferred from the filter to a tube for DNA extraction using a blade, and a FastDNA SPIN kit for soil (MP Biologicals, USA) was used for DNA extraction.

Primer pairs Arch-amoAF/Arch-amoAR (Francis et al., 2005) and amoA1F/amoA2R (Rotthauwe et al., 1997) were used for real-time PCR quantification of bacterial and archaeal amoA genes, respectively. We determined the abundances of AOA and AOB through real-time PCR using an iCycler iQ5 Thermocycler (Bio-Rad, USA) with the fluorescent dye SYBR-Green I. Amplification was performed according to the method described by Zhang et al. (2009) using 25- $\mu \mathrm{L}$ reaction mixtures that contained 12.5 $\mu \mathrm{L} \mathrm{SYBR}^{\circledR}$ Premix Ex Taq ${ }^{\mathrm{TM}}$ (Takara Biotechnology, Japan), $0.5 \mu \mathrm{L}$ of each primer $(10 \mu \mathrm{mol} / \mathrm{L}), 1 \mu \mathrm{L}$ bovine serum albumin $(25 \mathrm{mg} / \mathrm{mL})$, and $2 \mu \mathrm{L}$ of 10 -fold diluted or undiluted extracted DNA template (1-10 ng). Three replicates were analyzed for each sample. The plasmid DNA of known copy number of was tenfold serially diluted and analyzed in duplicate to generate an external standard curve. PCR efciencies were larger than $90 \%$ and correlation coefcients for standard curves were larger than 99\%. The DNA samples and standards were analyzed on the same plate and the results were analyzed using the $\mathrm{iQ}^{\mathrm{TM}} 5$ software (Bio-Rad, Richmond, USA).

\subsection{Data treatment}

The relationship between the abundance of the microbes and heavy metal concentration was analyzed through scatter plots. The Kolmogorov-Smirnov test for normality of the data was applied to determine if the data were normally distributed and non-normal data were log-transformed. 
Pearson's correlation coefficient was then calculated for data that were normally distributed, while those that could not be normally transformed were analyzed using Spearman's rho (Tabachnick and Fidell, 2007). In order to detect the correlation between the heavy metals and ammonia oxidizers on the whole, principle components analysis (PCA) was applied to the heavy metals and then based on the factor scores, multiple linear regression (MLR) was carried out between heavy metal factors and ammonia oxidizers. The concentrations of heavy metals and other parameters of each sampling site were described based on the mean, maximum and minimum values and standard deviation. A box plot was employed to display the microbial data. All statistical analyses were performed using SPSS 17.0 for Windows.

\section{Results}

\subsection{Physicochemical characteristics}

The physicochemical properties of the water samples indicated that the Fuyang River had high levels of ammonia and obvious hypoxia (Table 1). The average ammonia concentration was $17.71 \mathrm{mg} / \mathrm{L}$, which is much higher than the Chinese water quality standard of $2 \mathrm{mg} / \mathrm{L}$. Additionally, the maximum value was $60.28 \mathrm{mg} / \mathrm{L}$, indicating serious ammonia pollution in the Fuyang River. The average dissolved oxygen was only $1.4 \mathrm{mg} / \mathrm{L}$, and although this value varied greatly $(\mathrm{CV}=78 \%)$, only six of the 28 sites had levels greater than the limit of hypoxia $(2 \mathrm{mg} / \mathrm{L})$. The suspended particle concentration in the water was high, with a mean value of $197.20 \mathrm{mg} / \mathrm{L}$ and a maximum concentration as high as $700.00 \mathrm{mg} / \mathrm{L}$. The amount of suspended particles was sufficient for DNA extraction. The Fuyang River was also rich in organic matter because the average TOC content of our samples $(47.97 \mathrm{mg} / \mathrm{L}$, median $43.35 \mathrm{mg} / \mathrm{L})$ was much higher than the median TOC (7.0 $\mathrm{mg} / \mathrm{L}$ ) in rivers worldwide (Wetzel, 2001). The $\mathrm{pH}$ ranged from 6.6 to 8.5 , excluding site 19 , which had an extremely

Table 1 Physicochemical properties of water samples

\begin{tabular}{lllll} 
& \multicolumn{4}{c}{ Statistical description } \\
\cline { 2 - 5 } & Mean & CV & Min & Max \\
\hline $\begin{array}{l}\text { Dissolved } \\
\text { oxygen }(\mathrm{mg} / \mathrm{L})\end{array}$ & 1.4 & $78 \%$ & 0.1 & 5.0 \\
$\mathrm{pH}^{\mathrm{a}}$ & 7.6 & $5 \%$ & 6.6 & 8.5 \\
$\begin{array}{l}\text { Suspended } \\
\text { particles }(\mathrm{mg} / \mathrm{L})\end{array}$ & 197.20 & $70 \%$ & 37.14 & 700.00 \\
$\quad$ TOC $(\mathrm{mg} / \mathrm{L})$ & 47.97 & $60 \%$ & 9.79 & 119.09 \\
Ammonia $(\mathrm{mg} / \mathrm{L})$ & 17.71 & $80 \%$ & 0.92 & 60.28 \\
\hline
\end{tabular}

a The actual minimum $\mathrm{pH}$ is 2.37 at site 19 ; however, this was considered as an outlier and therefore excluded from the statistical description. $\mathrm{CV}$ : coefficient of variation. low $\mathrm{pH}$ of 2.37 because of the discharge of acid wastewater nearby. Overall, these findings indicate that the Fuyang River is highly polluted.

\subsection{Abundance of AOA and AOB}

Figure 2 shows the distribution of $\mathrm{AOA}$ and $\mathrm{AOB}$ in the Fuyang River. AOA abundance varied less than AOB, and AOA were generally more abundant than AOB. The abundance of AOA ranged from $10^{4.9}$ to $10^{2.7}$ gene copies $/ \mathrm{mL}$, but there was no significant difference among reaches. The highest value was observed at site 27 (Handan Reach), while the lowest was at site 6 (Hengshui Reach). However, at most sites, the AOA abundance was between $10^{3.1}$ (25th percentile) and $10^{3.8}$ (75th percentile) gene copies $/ \mathrm{mL}$. AOB varied more than AOA, with values of $10^{1.3}$ to $10^{4.8}$ gene copies/mL being observed; however, the difference among reaches was not significant. The minimum AOB abundance was observed at site 19 (Xingtai Reach), while the maximum value was observed at site 27 (Handan Reach). The ratio of AOA to AOB was larger than 1 at about $75 \%$ of the sites, and the greatest value of this ratio was primarily observed in the Hengshui and Xingtai reaches. In the natural environment, AOA are generally more abundant than AOB (Wessén et al., 2011; Leininger et al., 2006; Wu et al., 2010), and the abundance of AOA (Mincer et al., 2007) and AOB (Stehr et al., 1995) in the water column is commonly in the range of $10^{2}$ to $10^{5}$ gene copies/mL, which is consistent with the results of the present study.

\subsection{Distribution of heavy metals}

As shown in Fig. 3, the contents of $\mathrm{As}, \mathrm{Ni}$ and $\mathrm{Cr}$ in the upstream portion of the Fuyang River (Handan Reach) were generally lower than in other reaches, while $\mathrm{Zn}$ and $\mathrm{Cu}$ were distributed irregularly throughout the river system. Moreover, the levels of $\mathrm{Zn}, \mathrm{Cu}$ and $\mathrm{Cr}$ in the water were higher than the US EPA criteria throughout the river basin. The concentration of $\mathrm{Cr}$ ranged from 5.10 to $51.65 \mu \mathrm{g} / \mathrm{L}$, with an average value of $23.57 \mu \mathrm{g} / \mathrm{L}$. All sites exceeded the $\mathrm{Cr}$ criteria recommended by the US EPA except site 6 in Hengshui Reach and site 21 in Xingtai Reach. The Cr content in Handan Reach was constant and close to that of the criteria, while in other reaches the variation was great. The $\mathrm{Cu}$ content ranged from 15.77 to $179.10 \mu \mathrm{g} / \mathrm{L}$, and was much higher than the US EPA criteria. The $\mathrm{Zn}$ content was especially high and greatly exceeded the US EPA criteria of $120 \mu \mathrm{g} / \mathrm{L}$. The range of $\mathrm{Ni}$ levels was similar to that of $\mathrm{Cr}$, but much lower than the US EPA criteria. In Shijiazhang and Xingtai reaches, there was obvious variation in Ni content. Specifically, the highest level was observed at site 18 of Xingtai Reach. The concentration of As remained relatively stable, with a mean value of $10.16 \mu \mathrm{g} / \mathrm{L}$, which was well below the US EPA criteria of $150 \mu \mathrm{g} / \mathrm{L}$. The highest As level appeared in Shijiazhuang Reach, but the As contents in Hengshui and 


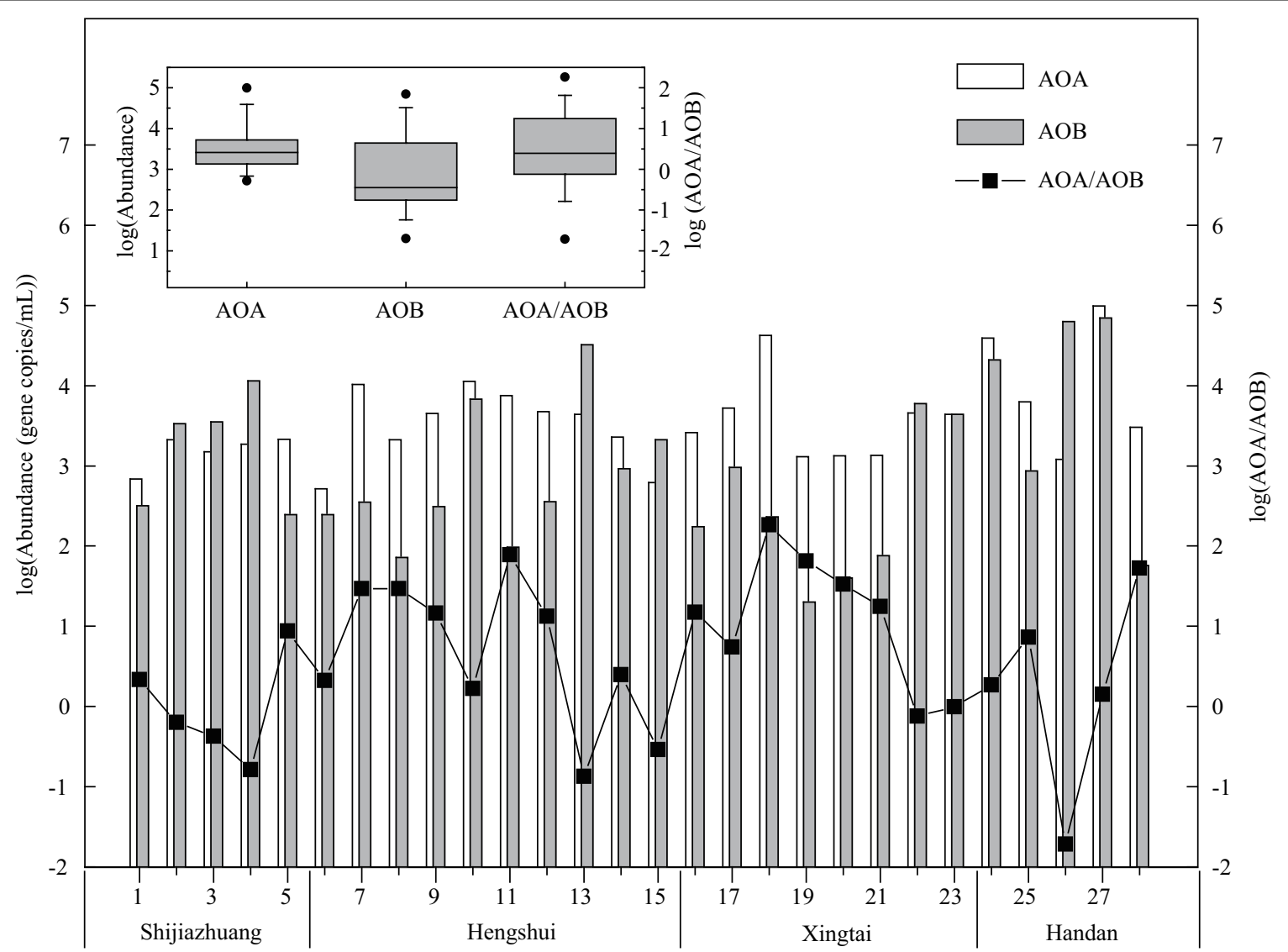

Fig. 2 Distribution of AOA and AOB in the Fuyang River. The inset plot is a statistic summary of all sites. The upper and bottom boundaries of each box indicate the 75 th and 25 th percentile respectively, while the mid-line represents the median. Whiskers above and below the box mark the 90 th and 10th percentile, respectively, while black dots are the maximum and minimum values.

Xingtai reaches were generally higher than in Shijiazhuang and Handan reaches. Overall, our results showed that the spatial variation of heavy metal content in the Fuyang River was dramatic and the levels of some heavy metals were high.

\subsection{Correlation between metals and microorganisms}

The K-S test indicated that all variables were normally distributed $(P>0.05)$, and the correlationship between physicochemical parameters and ammonia oxidizers was not significant $(P>0.05$, data not shown). While correlation analysis indicated that As displayed an inhibitory effect, $\mathrm{Ni}$ and $\mathrm{Zn}$ showed promoting effects and the remaining heavy metals exerted no significant effect on microorganisms (Fig. 4). Three heavy metals (As, Ni, $\mathrm{Zn}$ ) showed significant correlation with microbes, but the multiple correlation coefficient $\left(R^{2}\right)$ was low $(<0.4)$. The correlation type observed for AOA was positive, while that for AOB was negative. The As content showed no significant correlation with AOA abundance, but was negatively correlated with $\mathrm{AOB}(P<0.001) . \mathrm{Cr}$ and $\mathrm{Cu}$ were not correlated with AOA or AOB. Positive correlations were observed for Ni-AOA $(P<0.01)$ and $\mathrm{Zn-AOA}(P<0.05)$, indicating that increases in $\mathrm{Ni}$ and $\mathrm{Zn}$ in water can enhance the growth of AOA. However, neither Ni nor Zn showed a significant impact on AOB. It should be noted that when $\mathrm{Zn}$ was lower than $500 \mu \mathrm{g} / \mathrm{L}$, the variation in AOA abundance was so great that it deviated from the general trend of the overall data. Exclusion of these points during linear fitting resulted in the significance and the $R^{2}$ value being much greater (data not shown).

The results of PCA are shown in Table 2. According to the factor loadings, factor 1 was mainly composed by $\mathrm{Ni}$ and $\mathrm{Cr}$ and factor 2 was mainly composed by $\mathrm{Cu}, \mathrm{Zn}$ and

\begin{tabular}{lll}
\multirow{2}{*}{$\begin{array}{l}\text { Table } 2 \\
\text { heavy metals }\end{array}$} & Factor loadings obtained from a PCA carried out on the \\
Heavy metals & \multicolumn{2}{c}{ Component matrix } \\
\cline { 2 - 3 } & Factor 1 (34.7\%) & Factor 2 (31.3\%) \\
\hline $\mathrm{Cr}$ & 0.703 & -0.426 \\
$\mathrm{Ni}$ & 0.912 & 0.067 \\
$\mathrm{Cu}$ & 0.296 & 0.679 \\
$\mathrm{Zn}$ & 0.440 & 0.659 \\
As & 0.362 & -0.696
\end{tabular}

The PCA produced 5 factors and only factor 1 and factor 2 had eigenvalues larger than 1 ; value in the bracket is variance proportion explained by the factor. 


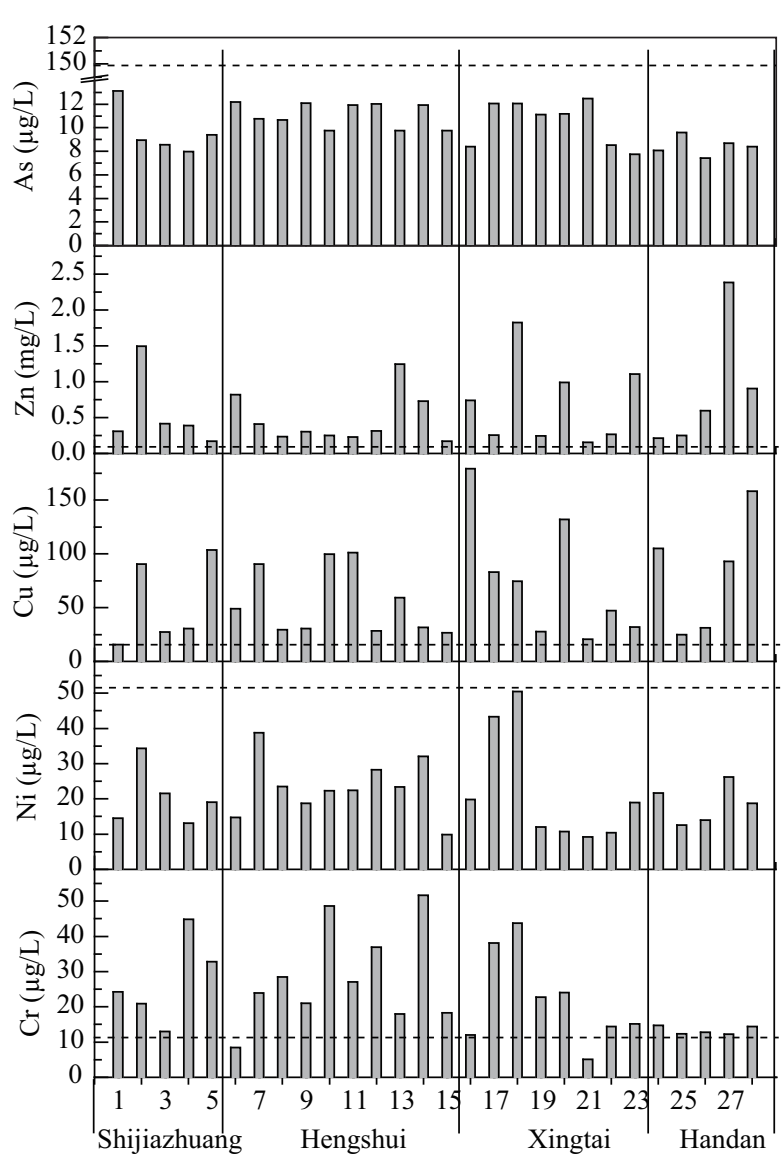

Fig. 3 Distribution of heavy metals in the Fuyang River. The dash is the US EPA recommended water quality criteria (chronic toxic level) of each metal in freshwater (US EPA, 2009). The criteria of $\mathrm{Cu}$ was calculated from a model, and ranged from 6.5 to $21 \mu \mathrm{g} / \mathrm{L}$. $21 \mu \mathrm{g} / \mathrm{L}$ was used in the present study. The criteria of $\mathrm{Cr}$ is the chronic toxicity level of $\mathrm{Cr}(\mathrm{VI})$.

As. However, the cumulative extraction of the two factors was only $66 \%$, indicating weak correlation among the 5 heavy metals. According to the result of MLR (Table 3), AOA can be well explained by the two factors because ANOVA was significant $(P<0.01)$. Factor $1(P<0.01)$ and Factor $2(P<0.05)$ both positively correlated with AOA, which meant the growth of AOA is promoted by heavy metals in the Fuyang River on the whole. However, AOB regression was not significant, indicating that $\mathrm{AOB}$ are less influenced by heavy metals than AOA on the whole.

Table 3 ANOVA results and regression coefficients of MLR carried out between abundance of $\mathrm{AOA}$ and $\mathrm{AOB}$ and factor scores of heavy metals

\begin{tabular}{llll} 
Ammonia oxidizers & $F$ & \multicolumn{2}{c}{$B$} \\
\cline { 3 - 4 } & & Factor 1 & Factor 2 \\
\hline AOA & $7.306^{* *}$ & $0.263^{* *}$ & $0.201^{*}$ \\
AOB & 1.811 & -0.085 & 0.344 \\
\hline
\end{tabular}

$F$ is ANOVA result and $B$ is the regression non-standard coefficient. * significant at $P<0.05$; ${ }^{* *}$ significant at $P<0.01$.
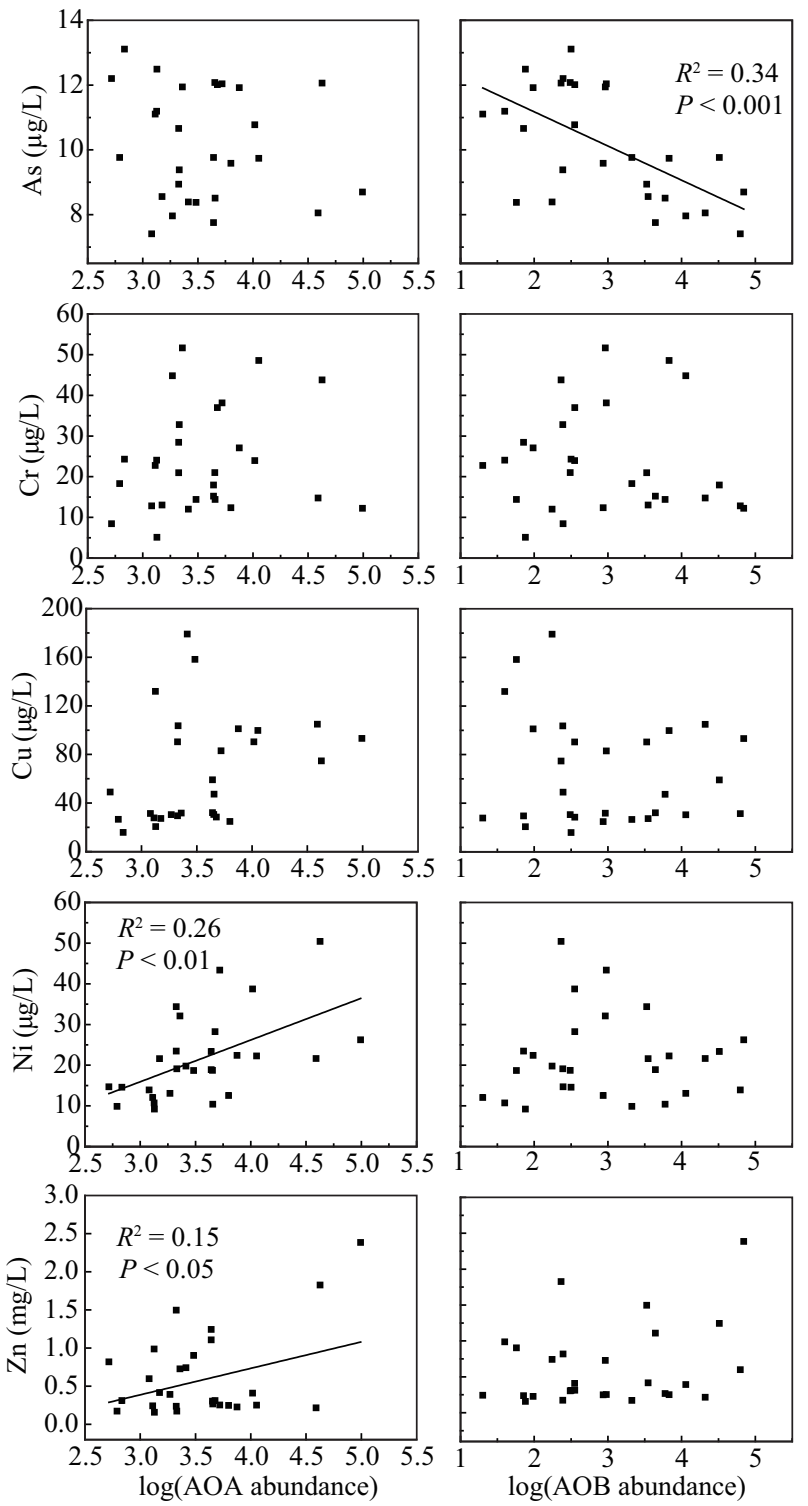

Fig. 4 Scatter plots of metals and microorganisms. The straight line is the linear fitting result, and scatter plots without lines indicate that the correlation is not significant.

\section{Discussion}

Nitrification is considered to be a surface-based process in water (Gantzer et al., 1988), and many studies have found that suspended solids play an important role in ammonia transformation in water (Brion et al., 2000; Xia et al., 2009). In the Fuyang River, high levels of ammonia and suspended substances have led to the water column playing a significant role in the process of ammonia transformation. Consequently, it is important to know the abundance of ammonia-oxidizing microorganisms in suspended materials and how they respond to environmental 
factors such as heavy metals.

A physiological effect curve of essential and nonessential elements (Stumm et al., 1996) can be used to explain the correlation results. Taking the element concentration as the horizontal ordinate gives a physiological effect curve of an essential element with two phases. Specifically, when the concentration is lower than the optimum value, which is always the water quality criteria, increasing concentration will be favorable, while when the concentration is above the optimum value, increasing concentrations will be toxic. Nonessential elements are much simpler, with toxic effects increasing with their concentration in a linear fashion.

As is a well-known toxin and it can be treated as a non-essential element. In the present study, As showed significant inhibitory effects toward AOB that conformed to the physiological effect curve. As primarily occurs as $\mathrm{As}(\mathrm{V})$ in $\mathrm{AsO}_{4}^{3-}$ and as $\mathrm{As}(\mathrm{III})$ in $\mathrm{AsO}^{2-}$. Structurally, arsenate is highly related to $\mathrm{PO}_{4}^{3-}$; thus, its toxicity mainly results from its interference with the metabolism of the major bioelement, phosphorus (Nies, 1999). During establishment of As criteria, the US EPA mentioned that this criterion was derived from data for As(III) (US EPA, 2009). However, As(V) may be the main form present in the Fuyang River, which would explain why an inhibitory effect appeared even though the As content was far below the criteria.

It is surprising that $\mathrm{Cr}$ had no effect on ammoniaoxidizing microorganisms since it is generally considered a toxic metal with no beneficial effects on microbes (Nies, 1999). This lack of effect may be attributed to the species of $\mathrm{Cr}$ and their concentrations. $\mathrm{Cr}$ primarily occurs as $\mathrm{Cr}(\mathrm{VI})$ in the divalent oxyanion chromate and as $\mathrm{Cr}(\mathrm{III})$ in the trivalent cation. The US EPA established chromium criteria for aquatic life based on the species. In freshwater, the criterion continuous concentration (chronic toxic level) for $\mathrm{Cr}(\mathrm{VI})$ is $11 \mu \mathrm{g} / \mathrm{L}$, while that for $\mathrm{Cr}(\mathrm{III})$, which is less toxic, is $74 \mu \mathrm{g} / \mathrm{L}$ (US EPA, 2009). Although the $\mathrm{Cr}$ content of many sites in the Fuyang River exceeded the $\mathrm{Cr}(\mathrm{VI})$ criteria, all had levels well below the $\mathrm{Cr}$ (III) criteria. Moreover, hexavalent $\mathrm{Cr}$ compounds (mainly chromates and dichromates) are much more mobile in soil/water systems than trivalent $\mathrm{Cr}$ compounds. The trivalent state is generally considered to be the stable form in equilibrium with most soil/water systems (Losi et al., 1994). In the Fuyang River, Cr probably primarily occurred in the form of $\mathrm{Cr}^{3+}$ and therefore did not inhibit ammonia-oxidizing microorganisms.

Nies (1999) pointed out that $\mathrm{Cu}$ has a dual character toward organisms. Specifically, its toxicity is based on the production of hydroperoxide radicals (RodriguezMontelongo et al., 1993) and on interaction with the cell membrane (Suwalsky et al., 1998). However, Cu is also an essential element for microbes that plays a key role in many enzymatic processes. In both bacterial and archaeal ammonia oxidation, the enzyme ammonia monooxygenase, which catalyzes the oxidation of ammonia to hydroxylamine $\left(\mathrm{NH}_{2} \mathrm{OH}\right)$, contains $\mathrm{Cu}$ and possibly Zn (Glass and Orphan, 2012). As a result, we can use the physiological effect curve of essential elements to predict how $\mathrm{Cu}$ will affect microorganisms in the Fuyang River. $\mathrm{Cu}$ was expected to inhibit microbial growth because the $\mathrm{Cu}$ content in the river was much greater than the criteria. However, the correlation between $\mathrm{Cu}$ and microbial abundance was not significant. This discrepancy may have occurred because free metal ions are generally the most toxic metal species owing to their high bioavailability (Tessier and Turner, 1995), and Cu easily forms complexes with organic matter in water $(\log K 7.7)$ (Wells et al., 1998), resulting in decreased levels of free ions. Since organic matter is abundant in the river, the complexation should be strong and free $\mathrm{Cu}$ ions in the Fuyang River likely decreased to the optimal range of the physiological curve; thus, no inhibitory effect was observed.

$\mathrm{Ni}$ can be treated as an essential element because $\mathrm{Ni}$ mediated catalysis is necessary for physiological processes such as splitting molecular or atomic hydrogen into protons and electrons (Nies, 1999). Ni likely had a promoting effect on microorganisms because the $\mathrm{Ni}$ content in the Fuyang River was below the criteria. Specifically, the concentration fell in the limiting region of the physiological effect curve and displayed a positive effect on the growth of ammonia-oxidizing microbes.

$\mathrm{Zn}$ is a component in a variety of enzymes and DNAbinding proteins that appears to be essential to life (Nies, 1999). As a result, $\mathrm{Zn}$ also corresponds to the physiological curve of essential elements. Although it is less toxic than other metals, the concentration of $\mathrm{Zn}$ in the Fuyang River was extraordinarily high and greatly exceeded the US EPA criteria. However, this metal showed a promoting effect on AOA. The free metal ions theory mentioned above likely accounts for this phenomenon. The conditional stability constant $(\log K)$ of $\mathrm{Zn}$ to form complexes with organic matter in water ranges from 6.8 to 11 (Wells et al., 1998; Tan et al., 1971; Bruland, 1989), which means that organic ligands are capable of forming strong complexes with $\mathrm{Zn}$ and reducing free $\mathrm{Zn}$ ions to extremely low levels. Therefore, free $\mathrm{Zn}$ ions for ammonia oxidation are still limiting, and the positive correlation between them is understandable.

At $\mathrm{Zn}$ levels $<500 \mu \mathrm{g} / \mathrm{L}$, the AOA abundances at some sites were unusually high. This was likely because the organic content at these sites was lower than at others, which decreased the $\mathrm{Zn}$ complexation and led to more free $\mathrm{Zn}$ ions being available for the growth of AOA. Further analysis of sites with $\mathrm{Zn}$ levels $<500 \mu \mathrm{g} / \mathrm{L}$ revealed a significant negative relationship between TOC and AOA (Fig. 5), which confirmed our assumption to some extent.

Interestingly, among the significant relationships between metals and microorganisms, positive effects (Ni 


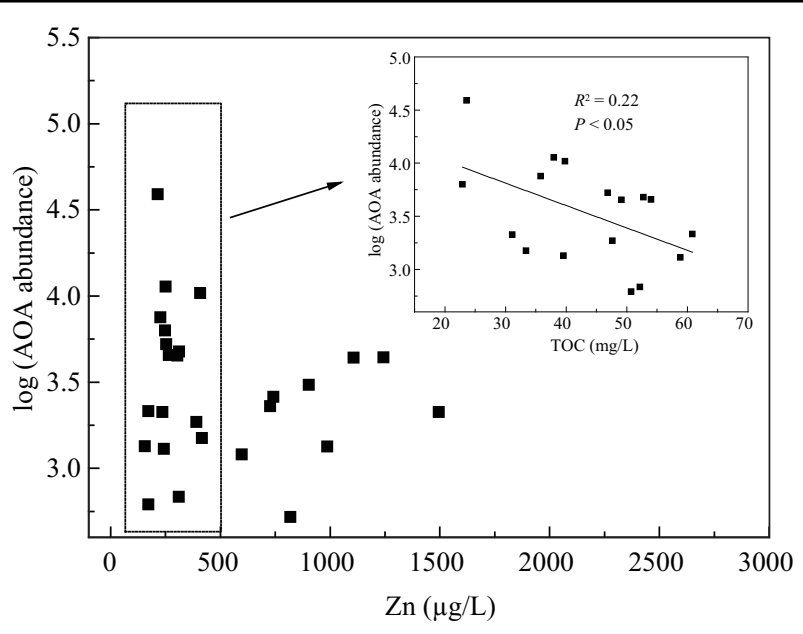

Fig. 5 Relationship between TOC and AOA abundance. The data points in the dashed box, which had $\mathrm{Zn}$ concentrations $<500 \mu \mathrm{g} / \mathrm{L}$, correspond to the points of the inset scatter plot. The straight line in the inset plot is the result of linear fitting.

and $\mathrm{Zn}$ ) only occurred in AOA, while negative effects (As) only occurred in AOB. This may have been because archaeal membranes are typically less permeable to ions than bacterial membranes (Kandler and König, 1998). This distinction makes archaea more tolerant to stress than bacteria (Valentine, 2007). Li et al. (2009) found that AOB were more sensitive to $\mathrm{Cu}$ contamination in the soil than AOA. These results coincide with those of our study, even though the inhibitor in the present study was arsenic in the water.

The multiple correlation coefficients $\left(R^{2}\right)$ were low for all significant relationships. This was because many factors, including organic matter in water, can affect the species and toxicity of heavy metals in the field environment. In addition to forming complexes, organic matter also has a redox effect on metals. Redman et al. (2002) found the organic matter facilitated the oxidation of As(III) to As(V), which have different toxicities. The $\mathrm{pH}$ and redox potential are also significant factors that impose important controls on metal species and the process of complexation (Stumm et al., 1996). The pH in the Fuyang River varied, although the extent was relatively small. However, dissolved oxygen, which has a great effect on redox potential, displayed distinct gradients across the watershed. Therefore, the physiological effects of heavy metals would be different even if the total concentration in water was the same.

The interaction among different metals may also a factor affecting the results of correlation analysis as well as MLR. The combined effect of heavy metals is complex and depends on the components of the mixtures as well as the organisms affected. It has been reported that $\mathrm{Cr}, \mathrm{Cu}, \mathrm{Ni}$ and $\mathrm{Zn}$ produced synergistic toxicity to the estuarine copepod (Hagopian-Schlekat et al., 2001). Cu and Zn were synergistic against the dinoflagellate but antagonistic against the diatom (Brk and Jensen, 1976). For microorganisms, the sum of toxicity of $\mathrm{Ni}$ and $\mathrm{Cu}$ individually was less than the combination of the two (Babich and Stotzky, 1983), and environmental factors such as $\mathrm{pH}$ can affect the microbial toxicity of heavy metals (Gikas, 2008). In this study, the synergism or antagonism among $\mathrm{Cr}, \mathrm{Ni}, \mathrm{Cu}, \mathrm{Zn}$ and $\mathrm{As}$ may lead to greater variance of AOA and AOB abundance than that when considering these metals individually, and we can attribute the weak correlationship between the heavy metals and ammonia oxidizers to this in part.

\section{Conclusions}

We investigated the abundance of ammonia-oxidizing microorganisms and content level of heavy metals in the Fuyang River. The limiting effect of heavy metals on the distribution of AOA and AOB was analyzed through statistical methods. Our results showed that AOA abundance varied less than $\mathrm{AOB}$, and $\mathrm{AOA}$ were generally more abundant than AOB. Compared with criteria recommended by the US EPA, Zn, Cu, Cr were high and As, Ni were low in the Fuyang River. However, correlation analysis indicated that As displayed an inhibitory effect, $\mathrm{Ni}$ and $\mathrm{Zn}$ showed promoting effects and the remaining heavy metals exerted no significant limiting effect on microorganisms. It was inferred that the physiological roles and environmental conditions, especially the organic matter in water, play an important role in the final effects of heavy metals.

\section{Acknowledgments}

This work was supported by the National Water Pollution Control and Management Technology Major Projects of China (No. 2012ZX07203-006, 2012ZX07203-003).

\section{R E F E R E N C E S}

Allison, S., Prosser, J., 1993. Ammonia oxidation at low $\mathrm{pH}$ by attached populations of nitrifying bacteria. Soil Biol. Biochem. 25(7), 935941.

Babich, H., Stotzky, G., 1983. Synergism between nickel and copper in their toxicity to microbes: Mediation by $\mathrm{pH}$. Ecotoxicol. Environ. Saf. 7(6), 576-587.

Bræk, G.S., Jensen, A., 1976. Heavy metal tolerance of marine phytoplankton. III. Combined effects of copper and zinc ions on cultures of four common species. J. Experim. Marine Biol. Ecol. 25(1), 3750.

Brion, N., Billen, G., Guzennec, L., Ficht, A., 2000. Distribution of nitrifying activity in the Seine River (France) from Paris to the estuary. Estuaries and Coasts 23(5), 669-682.

Bruland, K.W., 1989. Complexation of zinc by natural organic ligands in the central North Pacific. Limnol. Oceanogr. 34(2), 269-285.

Brümmer, G., Gerth, J., Herms, U., 2007. Heavy metal species, mobility and availability in soils. Zeitschrift fr Pflanzenernhrung und Bodenkunde 149(4), 382-398.

Clesceri, L.S., Greenberg, A.E., Eaton, A.D., 1998. Standard Methods 
for the Examination of Water and Wastewater. 20th Edition. APHA American Public Health Association, Washington, D.C.

Erguder, T.H., Boon, N., Wittebolle, L., Marzorati, M., Verstraete, W., 2009. Environmental factors shaping the ecological niches of ammonia-oxidizing archaea. FEMS Microbiol. Rev. 33(5), 855869.

Francis, C.A., Beman, J.M., Kuypers, M.M.M., 2007. New processes and players in the nitrogen cycle: the microbial ecology of anaerobic and archaeal ammonia oxidation. ISME J., 1(1), 19-27.

Francis, C.A., Roberts, K.J., Beman, J.M., Santoro, A.E., Oakley, B.B., 2005. Ubiquity and diversity of ammonia-oxidizing archaea in water columns and sediments of the ocean. Proc. Natl. Acad. Sci. USA 102(41), 14683-14688.

Gantzer, C.J., Rittmann, B.E., Herricks, E.E., 1988. Mass transport to streambed biofilms. Water Res., 22(6), 709-722.

Gikas, P., 2008. Single and combined effects of nickel (Ni(II)) and cobalt $(\mathrm{Co}(\mathrm{II}))$ ions on activated sludge and on other aerobic microorganisms: A review. J. Hazard. Mater. 159(2), 187-203.

Giller, K.E., Witter, E., Mcgrath, S.P., 1998. Toxicity of heavy metals to microorganisms and microbial processes in agricultural soils: A review. Soil Biol. Biochem., 30(10-11), 1389-1414.

Ginzinger, D.G., 2002. Gene quantification using real-time quantitative PCR: an emerging technology hits the mainstream. Exp. Hematol. 30(6), 503-512.

Glass, J.B., Orphan, V.J., 2012. Trace metal requirements for microbial enzymes involved in the production and consumption of methane and nitrous oxide. Front. Microbiol. 3.

Hagopian-Schlekat, T., Chandler, G., Shaw, T.J., 2001. Acute toxicity of five sediment-associated metals, individually and in a mixture, to the estuarine meiobenthic harpacticoid copepod Amphiascus tenuiremis. Marine Environ. Res., 51(3), 247-264.

He, J., Shen, J., Zhang, L., Zhu, Y., Zheng, Y., Xu, M. et al., 2007. Quantitative analyses of the abundance and composition of ammonia-oxidizing bacteria and ammonia-oxidizing archaea of a Chinese upland red soil under long-term fertilization practices. Environ. Microbiol. 9(9), 2364-2374.

Kandler, O., König, H., 1998. Cell wall polymers in archaea (archaebacteria). Cell. Mol. Life Sci. 54(4), 305-308.

Koops, H.P., Pommerening-Rser, A., 2006. Distribution and ecophysiology of the nitrifying bacteria emphasizing cultured species. FEMS Microbiol. Ecol. 37(1), 1-9.

Leininger, S., Urich, T., Schloter, M., Schwark, L., Qi, J., Nicol, G. et al., 2006. Archaea predominate among ammonia-oxidizing prokaryotes in soils. Nature, 442(7104), 806-809.

Li, X., Zhu, Y.G., Cavagnaro, T.R., Chen, M., Sun, J., Chen, X. et al., 2009. Do ammonia-oxidizing archaea respond to soil $\mathrm{Cu}$ contamination similarly as ammonia-oxidizing bacteria? Plant Soil 324(1-2), 209-217.

Liu, Y.R., Zheng, Y.M., Shen, J.P., Zhang, L.M., He, J.Z., 2010. Effects of mercury on the activity and community composition of soil ammonia oxidizers. Environ. Sci. Pollut. Res. 17(6), 1237-1244.

Losi, M., Amrhein, C., Frankenberger, W. Jr,, 1994. Environmental biochemistry of chromium. Rev. Environ. Contam. Toxicol., 136: 91-121.

Martens-Habbena, W., Berube, P.M., Urakawa, H., de La Torre, J.R., Stahl, D.A., 2009. Ammonia oxidation kinetics determine niche separation of nitrifying archaea and bacteria. Nature, 461(7266), 976-979.
Mertens, J., Broos, K., Wakelin, S.A., Kowalchuk, G.A., Springael, D., Smolders, E., 2009. Bacteria, not archaea, restore nitrification in a zinc-contaminated soil. The ISME J. 3(8), 916-923.

Mertens, J., Wakelin, S.A., Broos, K., McLaughlin, M.J., Smolders, E., 2010. Extent of copper tolerance and consequences for functional stability of the ammonia-oxidizing community in long-term copper-contaminated soils. Environ. Toxicol. Chem. 29(1), 27-37.

Mincer, T.J., Church, M.J., Taylor, L.T., Preston, C., Karl, D.M., DeLong, E.F., 2007. Quantitative distribution of presumptive archaeal and bacterial nitrifiers in Monterey Bay and the North Pacific Subtropical Gyre. Environ. Microbiol., 9(5), 1162-1175.

Nies, D.H., 1999. Microbial heavy-metal resistance. Appl. Microbiol. Biotechnol., 51(6), 730-750.

Okano, Y., Hristova, K.R., Leutenegger, C.M., Jackson, L.E., Denison, R.F., Gebreyesus, B. et al., 2004. Application of real-time PCR to study effects of ammonium on population size of ammoniaoxidizing bacteria in soil. Appl. Environ. Microbiol. 70(2), 1008-1016.

Redman, A.D., Macalady, D.L., Ahmann, D., 2002. Natural organic matter affects arsenic speciation and sorption onto hematite. Environ. Sci. Technol. 36(13), 2889-2896.

Rodriguez-Montelongo, L., de la Cruz-Rodriguez, L.C., Faras, R.N., Massa, E.M., 1993. Membrane-associated redox cycling of copper mediates hydroperoxide toxicity in Escherichia coli. Biochim. Biophys. Acta (BBA)-Bioenergetics 1144(1), 77-84.

Rotthauwe, J.H., Witzel, K.P., Liesack, W., 1997. The ammonia monooxygenase structural gene amoA as a functional marker: Molecular fine-scale analysis of natural ammonia-oxidizing populations. Appl. Environ. Microbiol. 63(12), 4704-4712.

Ruyters, S., Mertens, J., Springael, D., Smolders, E., 2010. Stimulated activity of the soil nitrifying community accelerates community adaptation to Zn stress. Soil Biol. Biochem. 42(5), 766-772.

Schramm, A., De Beer, D., Gieseke, A., Amann, R., 2000. Microenvironments and distribution of nitrifying bacteria in a membrane-bound biofilm. Environ. Microbiol. 2(6), 680-686.

Stehr, G., Böttcher, B., Dittberner, P., Rath, G., Koops, H.P., 1995. The ammonia-oxidizing nitrifying population of the River Elbe estuary. FEMS Microbiol. Ecol. 17(3), 177-186.

Stumm, W., Morgan, J., Drever, J., 1996. Aquatic chemistry: Chemical equilibria and rates in natural waters. Wiley, New York.

Suwalsky, M., Ungerer, B., Quevedo, L., Aguilar, F., Sotomayor, C.P., 1998. $\mathrm{Cu}^{2+}$ ions interact with cell membranes. J. Inorg. Biochem., 70(3-4), 233-238.

Tabachnick, B.G., Fidell, L. S., 2007. Using multivariate statistics. Pearson/Allyn and Bacon, Boston.

Tan, K.H., King, L.D., Morris, H.D., 1971. Complex reactions of zinc with organic matter extracted from sewage sludge. Soil Sc. Soc. Am. J. 35(5), 748-752.

Tessier, A., Turner, D.R., 1995. Metal speciation and bioavailability in aquatic systems. Wiley.

Treusch, A.H., Leininger, S., Kletzin, A., Schuster, S.C., Klenk, H.P., Schleper, C., 2005. Novel genes for nitrite reductase and Amo-related proteins indicate a role of uncultivated mesophilic crenarchaeota in nitrogen cycling. Environ. Microbiol. 7(12), 1985-1995.

US EPA, 2009. National Recommended Water Quality Criteria. http://water.epa.gov/scitech/swguidance/standards/criteria/current/ index.cfm. 
Valentine, D.L., 2007. Adaptations to energy stress dictate the ecology and evolution of the archaea. Nature Rev. Microbiol. 5(4), 316323.

Venter, J.C., Remington, K., Heidelberg, J.F., Halpern, A.L., Rusch, D., Eisen, J.A. et al., 2004. Environmental genome shotgun sequencing of the Sargasso Sea. Science 304(5667), 66.

Wells, M.L., Kozelka, P.B., Bruland, K.W., 1998. The complexation of 'dissolved' $\mathrm{Cu}, \mathrm{Zn}, \mathrm{Cd}$ and $\mathrm{Pb}$ by soluble and colloidal organic matter in Narragansett Bay, RI. Mar. Chem. 62(3-4), 203-217.

Wessén, E., Söderström, M., Stenberg, M., Bru, D., Hellman, M., Welsh, A. et al., 2011. Spatial distribution of ammonia-oxidizing bacteria and archaea across a 44-hectare farm related to ecosystem functioning. The ISME J. 5(7), 1213-1225.
Wetzel, R.G., 2001. Limnology: Lake and river ecosystems. Academic Press.

Wu, Y., Xiang, Y., Wang, J., Zhong, J., He, J., Wu, Q.L., 2010. Heterogeneity of archaeal and bacterial ammonia-oxidizing communities in Lake Taihu, China. Environ. Microbiol. Reports, 2 (4), 569-576.

Xia, X., Yang, Z., Zhang, X., 2009. Effect of suspended-sediment concentration on nitrification in river water: Importance of suspended sediment-water interface. Environ. Sci. Technol., 43(10), 36813687.

Zhang, L.M., Wang, M., Prosser, J.I., Zheng, Y.M., He, J.Z., 2009. Altitude ammonia-oxidizing bacteria and archaea in soils of Mount Everest. FEMS Microbiol. Ecol., 70(2), 208-217. 